\title{
HÁJKOVÁ, D. - HORÁK, P. - KESSLER, V. - MICHELA, M. (eds.). Sláva republice! Oficiální svátky a oslavy v meziválečném Československu.
}

\author{
Praha: Academia - Masarykův ústav a Archiv AV ČR, 2018, 536 s.
}

Ke stoletému výročí založení Československé republiky snesla česká badatelská obec na oltáŕ vědy mnohé dary, jedním z velmi povedených je publikace Sláva republice! Oficiální svátky a oslavy v meziválečném Československu, kterou vydala v jubilejním roce 2018 Academia ve spolupráci s Masarykovým ústavem a Archivem AV ČR. Obsáhlá publikace o více než pěti stovkách stran s bohatou obrazovou dokumentací zkoumá vliv jednotlivých svátků, památných dnů a oslav na budování identity nového státu a sounáležitosti jeho občanů s ním. Šestice autorů se v deseti kapitolách věnuje různým aspektům dané problematiky. Byt' jsou kapitoly na sobě nezávislé a nic nebrání číst je samostatně, ve svém celku a řazení poskytují čtenáři komplexní obraz meziválečných svátků a oslav a navzájem se vhodně doplňují.

Jana Čechurová v první kapitole věnující se nejen právnímu zakotvení státních svátků v zákoně o svátcích a památných dnech, nýbrž i otázce státních symbolů, pojednává především o bouřlivých debatách, které přijetí zákona předcházely, a též o snahách určitých politických skupin o novelizaci tohoto předpisu. Právě státní svátky a jejich právní zakotvení odrážely snahu nového establishmentu o důsledný rozchod s dosavadní monarchistickou tradicí a jejími symboly. Neshody a rozmíšky mezi politickými aktéry, které s přijetím zákona souvisely, byly důsledkem odlišného vnímání výsledku první světové války a nové státoprávní situace, stejně tak rozdílným vnímáním církevních svátků v Čechách, na Moravě a ve Slezsku, na Slovensku a Podkarpatské Rusi. Nutno podotknout, že otázka státních svátků nebyla jen otázkou symbolickou, nýbrž i ryze praktickou. Vynořily se spolu s ní totiž rovněž pracovněprávní otázky, které ze dnů budou dny pracovního volna a u kterých z toho důvodu vyvstane nutnost př́ijmové kompenzace. Zákon vedle státního svátku 28. ř́ijna, vyhlášeného záhy po vzniku republiky, přidal další památné dny, které ač mnohé církevního charakteru, získaly zákonným zakotvením nový - státní charakter.

Druhá kapitola z pera autorské dvojice Dagmar Hájkové a Miroslava Michely se věnuje svátku z největších, a to právě 28. říjnu - dnu československé státnosti. Jeho postavení mezi legislativně zakotvenými svátky bylo o to výjimečnější, že byl zákonem za státní svátek prohlášen již necelý rok po vzniku republiky, 14. ř́jna 1919. Není bez zajímavosti, že samotný „,den D“ nového státu byl předmětem vážných diskuzí. Někteří za počáteční den nového státního zřízení počítali již 14. říjen 1918, kdy byla pořádána generální stávka, při které na několika místech došlo k spontánnímu vyhlášení republiky, 18. říjen, kdy byla přijata Washingtonská deklarace nezávislosti, 30. ř́jen, kdy byla přijata Martinská deklarace a slovenští představitelé vyjádřili svobodnou a nezávislou vủli stát se součástí česko-slovenského celku nebo až 14. listopad, kdy se sešlo Prozatímní národní shromáždění. 
K označení 28. ř́jna za výchozí bod československé státnosti se postavil jak Tomáš Garrigue Masaryk, tak například Ferdinand Peroutka, a to s argumentem, že právě tento den došlo k materiálnímu vzniku samostatného státu, který tak byl občanstvem všeobecně přijat. Čtenář se seznámí se slavením svátku ve školách, na manifestacích, s povinnou i žádanou výzdobou, i se spory mezi př́slušníky jednotlivých národností během oslavovaného svátku. Detailně pojednáno je o sinusoidě oslav, jak o velkolepém výročí oslav decennia roku 1928, svorných oslavách v letech třicátých, kdy od hranic s Německem již vála nenávistná rétorika, tak o poslední oficiální oslavě roku 1937 nedlouho po Masarykově pohřbu, který jako by symbolicky uzavíral dobu svobody a míru. 28. ř́jen 1938 pak už byl skutečně jen labutí písní masarykovského Československa.

Mezi oslavy mladého státu bylo třeba zařadit nepochybně 7. březen, narozeniny Prezidenta Osvoboditele Tomáše Garrigua Masaryka, kterým se věnují Dagmar Hájková a Pavel Horák. Po více než šesti desetiletích vlády Františka Josefa I., jehož srpnové narozeniny patřily mezi pravidelné slavnosti v celé podunajské monarchii, na tuto tradici oslav narozenin hlavy státu pragmaticky navázala i nová republika. Prezident se stal jedním ze symbolů nové doby, modlou, filozofem na trůně s promyšleně budovanou aureolou ,,tatíčka“. Republiku zaplavovaly bronzové i sádrové busty, tisk chrlil oslavné básně. Vtipně poznamenal Jan Masaryk, že při cestě z vinárny na něj otec shlíží z každého výkladu. Československo mělo štěstí na dvě Masarykova jubilea, a to sedmdesátiny v roce 1920 a osmdesátiny o deset let později. Darů k osmé dekádě bylo dokonce přes třináct stovek a k jejich prezentaci byla uspořádána ve Vladislavském sále výstava. Narozeniny otce zakladatele našly dokonce odezvu i mezi občany jiné národnosti než československé. Občané německé národnosti jej uznávali jako nespornou osobnost mezinárodního významu, občané národnosti polské svůj vřelý vztah nejednou deklarovali kupř́ikladu udělením čestného občanství. Výjimku tvořil komunistický tisk, který i přes sváteční náladu u př́ležitosti narozenin hlavy státu oslavy ignoroval a vehementně se věnoval oslavám Mezinárodního dne žen o den později. Přestože tedy nebyl tento den oficiálním státním svátkem, hojně se slavil a byl jedním z mála svátků, které spojovaly pestrou paletu příslušníků národnostních menšin. Je zajímavou perličkou, že památným dnem ex lege byl v letech 1946-1951. Autory nebyly zapomenuty ani předválečné oslavy narozenin Prezidenta Budovatele Edvarda Beneše, který takové oslavy považoval za možnost prezentace národní svornosti v rozbouřené době.

Významné místo mezi meziválečnými svátky má jistě památka bitvy u Zborova konané 2. července 1917, proto si zasloužila v publikaci svou objemnou kapitolu sepsanou Vojtěchem Kesslerem. Jednalo se o svátek takř́ikajíc dvojsečný. Na jednu stranu byl bezesporu připomínkou hrdinství a vítězství československých legionářủ a nesporně patří k zakladatelskému mýtu nového státu, na druhou stranu však coby národní, nikoli státní svátek v pravém slova smyslu akcentoval hrdinství pouze jedné skupiny obyvatel - Čechů, popř. Slováků. V mnohonárodnostním státě, jakým Československo bylo, se ale ostatní menšiny z těchto důvodů se svátkem nemohly ztotožnit. Od Zborova, dosud neznámé vesnice, která se přes noc stala modlou, se domů vraceli ,první občané republiky“, kteří byli pevnými pilírí státu. Československo pak zažilo dvě velká, masově oslavovaná výročí slavné bitvy, která se stala „oslavou maskulinního heroismu a sebeobětování“. Svátek byl neodmyslitelně spjat s oslavou mužské síly a odhodlanosti, zborovští a jiní veteráni předávali symbolickou štafetu mladíkům, kteří slibovali oddaně bránit vlast. Republikou hýbaly 
plamenné projevy hlav státu, ministrů národní obrany, dokonalé formace vojska a sokolů, čestné stráže se střídaly u hrobů neznámých vojínů. Neznámý vojín exhumovaný u Zborova, který byl za prŕitomnosti čestné stráže převezen na československo-polskou hranici do Petrovic u Karviné, odkud putoval s četnými zastávkami pro vzdání úcty až do Prahy, byl slavnostně v rámci oslav 5. výročí bitvy uložen v malé kapli Staroměstské radnice. Tam vydržel až do začátku čtyřicátých let, kdy byl německou správou zcela zlikvidován. Kapitola nezapomíná na válečné pomníky padlým, at' už ryze národnostní, kdy byli uctíváni padlí jednotlivých menšin, popř. většin, tak též ty ojediněle „,inkluzivní“, které zahrnovaly padlé oběti bez ohledu na příslušnost k národnosti či bojující straně, jakým je např́iklad památník obětem války v Moravské Ostravě. Odraz zborovské bitvy v kultuře, tedy literatuře, divadle i filmu je důslednou tečkou za zevrubně popsaným svátkem, který dnes v povědomí těch, jejichž pradědové v jeho rámci př́isahali věrnost republice a ideálům demokracie, padá do propadliště velkých dějin.

Jak praví Mácha, první máj je lásky čas. K oslavě však zval nejen hrdliččin hlas, nýbrž i tribunové levicových politických stran označeni už tehdy karafiátem během oslav svátku práce. Svátek se slavil již od roku 1890, tři roky po potlačení dělnických demonstrací v Chicagu, které se staly původcem vzniku mezinárodního svátku pracujících. Prvnímu máji tak byla věnována další kapitola z pera Pavla Horáka. Prvního máje 1918, poslední oslavy za trvání habsburské monarchie, který se stal i díky účasti politiků občanských stran po boku socialistů všenárodní demonstrací jednoty, se účastnilo 150 tisíc lidí jen v Praze, přes půl milionu pak v celých Čechách. 1. máj 1919 byl již oficiálně novou vládnoucí garniturou označen za svátek národní, což bylo v poválečné Evropě ojedinělým a vskutku unikátním počinem. Jednotlivé politické strany, předně socialistická a posléze komunistická, se předháněly ve velkoleposti svých průvodů, táborů lidu, manifestací a provolání. Nesocialistické strany, at’ už národní socialisté, národní demokraté, lidovci či živnostníci, se spokojily s nevelkými oslavami, které měly v jejich tradičních baštách zabránit tomu, aby se svátku zcela zmocnily socialistické síly. Politické strany byly masově vytlačeny z bat'ovského Zlína, kde Bat'ova společnost sama pořádala okázalé svátky práce, vůdčí hodnoty celého koncernu, což kapitola nepomíjí a obšírně se i tomuto fenoménu věnuje. První máj si s malou výjimkou za dob Slovenského státu uchoval své postavení zákonného svátku bez přerušení až do dnešních dnů, byt' v mnohem menším měřítku, což snad můžeme považovat za důsledek masových oslav ve čtyřicetiletém období totalitního režimu, které svou vyprázdněností zanechaly ve vzpomínkách mnohých jistou pachut'.

Dagmar Hájková s Evou Hajdinovou se společně pustily do zpracování odkazu Jana Husa a nejen meziválečných oslav jeho mučednické smrti, které však zvlášt' na Slovensku a mezi českými Němci budily rozpaky. Rozboru se dočkalo srovnání oslav husovských s oslavami sv. Jana Nepomuckého, stejně tak neshody s katolickou církví, která se proti ustanovení 6. července za oficiální svátek bránila. Když převzal prezident Masaryk záštitu nad oslavami 510. výročí Husova upálení a ministerský předseda Švehla se stal čestným členem organizačního výboru oslav, opustil přesně v den svátku papežský nuncius Francesco Marmaggi demonstrativně Prahu. Ohromné oslavy u Šalounova pomníku na Staroměstském náměstí se neobešly bez čestné stráže, kladení věnců, zpěvu, recitace a projevů významných řečníků, at’ už starosty místního výboru Josefa Rotnágla nebo rektora Univerzity Karlovy Josefa Drachovského. Den nato pozdravil slavící obyvatelstvo prezident spolu s premiérem. Cenou za mohutné oslavy nejen v pražských ulicích 
a ostentativního přihlášení se Hradu k husovské tradici byla mezinárodní roztržka se Svatým stolcem, stejně tak vnitrostátní se slovenskými a německými katolíky. I přes to se právě od roku 1925 dá hovořit o státním charakteru svátku, nejen o spontánně slaveném významném dni. Jeho význam a oslavy však ztrácely na lesku a masovosti již za první republiky, natož po válce. Po roce 1948 byl dni odňat jeho sváteční charakter a Hus byl nově zdůrazňován v souladu s politickou koncepcí jako první revolucionár. Dnešní význam svátku a jeho manifestační charakter necht' posoudí čtenář sám.

Nepominutelný je též svátek věrozvěstů sv. Cyrila a Metoděje, jemuž se obsáhle věnuje Miroslav Michela v souvislosti s politizací tohoto církevního svátku. Pozornost je věnována vývoji svátku samotného, a to od středověku až do 20. století. V prostředí nové republiky byl shodně akcentován nejen církví katolickou, ale i evangelickou a pravoslavnou, a byl nadále neodmyslitelně spjat s moravským Velehradem. Na Slovensku pak byl svátek, oslavovaný především v oblasti okolo Nitry, vítanou protiváhou k uherským světcům. Oficiální postoj státu ke svátku ale nebyl kdovíjak kladný, cyrilometodějská tradice nebyla v souladu s proklamovaným husovským, reformačním postojem prezidenta Masaryka, který bezesporu vztah ke katolíkům a jejich svátkům komplikoval. I přes tyto nesouladné postoje se svátek slovanských bratři dostal do oficiálního státního svátkového kalendáře a jejich památka tak byla postavena naroveň památky Jana Husa a sv. Václava, roli svátku všenárodního a stmelujícího však nesehrál. Ač sice spojoval Čechy a Slováky, rozděloval katolíky a pokrokáře. Nemalá pozornost je věnována nejen oslavám velehradským, ale stejně tak slovenským, které rovněž stavěly na velkomoravských idejích. Svátek dosáhl svého vrcholu paradoxně až za Slovenského státu, kdy se stal jedním z nejvýznamnějších. V poválečné době jej mistrně uchopil až katolický disent, roku 1980 byli věrozvěstové papežem dokonce vyhlášeni za spolupatrony Evropy. Jejich svátek zná český i slovenský kalendár̆ dodnes.

Každá země má svého světce, Uhry sv. Štěpána, Polsko sv. Stanislava, Rakousy sv. Leopolda. K Čechám neodmyslitelně patří sv. Václav, štědrý, zbožný a zdrženlivý kníže české země, který nedá zahynouti nám, ni budoucím. Od roku 1848 mu patří jedno z největších pražských náměstí, které od roku 1913 zdobí jeho socha, jak ji známe dnes. Roku 1909 při oslavách údajného 980. výročí mučedníkovy smrti plály na Vltavě tisíce bengálských svící, které společně tvořily svatováclavskou korunu. 28. ř́ína 1918 byl Myslbekův pomník svědkem vyhlášení československé samostatnosti. Právě sv. Václav, kterému se věnuje další kapitola z pera Evy Hajdinové, měl v nové republice symbolizovat tisíciletou kontinuitu českého státu. Vrcholem svatováclavských oslav bylo milénium roku 1929, které vycházelo z tehdejší oficiální datace mučedníkovy smrti. V tomto roce se konaly četné výstavy, vydávaly se zvláštní tisky, pohlednice, konaly se velkolepé veřejné oslavy a slavnostní bohoslužby. Poprvé od vzniku republiky byly v hlavní lodi svatovítské katedrály načas vystaveny korunovační klenoty. 28. září 1929 byla dokončená katedrála oficiálně otevřena. Je zajímavé, že o co méně byl kult sv. Václava živý na Slovensku, o to více rezonoval mezi českými Němci. I přes zneužití svatováclavské památky v době protektorátu a poválečné snaze vymazat církevní svátky z povrchu zemského, nese dodnes sv. Václav své kopí v srdci matičky Prahy a smíŕlivě dohlíží na ty, kteří se kolem něj již přes sto let shlukují.

Vojtěch Kessler a Miroslav Michela se v samém závěru publikace věnují ve dvou kapitolách svátku „německých Dušiček“" a uhersko-mad’arským tradicím. Německá menšina 
dokázala politicky vytěžit maximum z přestřelek mezi českým vojskem a německými stávkujícími, kteří chtěli 4. března 1919 vyjádřit svůj nesouhlas s přičleněním sudetoněmeckých provincií k Československu, které si v celé zemi vyžádaly celkem 54 obětí, kterých se umně ujala sudetoněmecká propaganda. Autor mistrně popisuje vývoj fenoménu těchto oslav, který je v jistých kruzích překvapivě živý až do dnešních dnů. Neméně konfliktní byl vztah s mad'arskou menšinou, která po vyhlášení Československa přišla o své výsadní postavení, četné pomníky a svátky. Též proto existovala silná potřeba mad'arské menšiny uchovat alespoň oslavy svátku sv. Štěpána, s čímž však československé úřady nejenže nesouhlasily, ale snažily se oslavám aktivně zabránit, stejně jako oslavám uhersko-mad'arské liberální revoluce. Výčet svátků a památných dnů by nebyl úplný, kdyby nebyly zmíněny svátky jednotlivých menšin, které se s oficiálními československými festivitami neztotožnily. Je proto dobře, že své místo dostaly i události a s nimi spojené oslavy a připomínky, ačkoli se nejednalo o svátky státem protežované a organizované.

Dnes, kdy se jednotlivé státní svátky až na výjimky odbydou lakonickou notickou v tisku a skromnou reportáží v masmédiích, působí dokument o masových „všenárodních“ oslavách až nepatřičně. Publikace přináší nespočet zajímavých faktů a otázek. Zamýšlel československý zákonodárce svým včleněním Prvního máje do svátkového kalendáře jen projev úcty ke svátku práce, bytostně spojenému s dělnickým hnutím, nebo vnímal v evropských poměrech zcela výjimečnou etatizaci tohoto dne jako možnost kontroly „sociálního ventilu“ společnosti? Mohly vést mohutné oslavy svátku Mistra Jana Husa se silnou národní, protikatolickou a protiněmeckou ideou ke sjednocení různorodé československé společnosti dělící se nejen národnostně, ale i nábožensky? Svůj prostor v publikaci našly, a to zcela zaslouženě, též svátky tzv. alternativní. Jednalo se o svátky, které slavili výhradně př́slušníci té které národnostní menšiny, a které představovaly jakési zrcadlo svátkům oficiálním, československým a svým vyzněním jistě čechoslovakizačním. Publikace je ve svém celku kronikou meziválečných svátků a pamětních dní, a to nejen těch oficiálních. Poutavé texty, bohatá obrazová př́iloha a reprezentativní provedení z ní tak dělají ozdobu každé knihovny.

Dominik Macek

doi: 10.14712/2464689X.2020.24 